\title{
Connexin 50 Mutation Lowers Blood Pressure in Spontaneously Hypertensive Rat
}

\author{
O. ŠEDA ${ }^{1,2}$, F. LIŠKA ${ }^{1}$, M. PRAVENEC ${ }^{1,3}$, Z. VERNEROVÁ $^{4}$, L. KAZDOVÁ $^{5}$, \\ D. KŘENOVÁ ${ }^{1}$, V. ZÍDEK ${ }^{3}$, L. ŠEDOVÁ ${ }^{1,2}$, M. KRUPKOVÁ ${ }^{1}$, V. KŘEN ${ }^{1}$
}

${ }^{1}$ Institute of Biology and Medical Genetics, First Faculty of Medicine, Charles University, Prague, Czech Republic, ${ }^{2}$ Laboratory of Rat Models of Metabolic Disorders, Division BIOCEV, Institute of Molecular Genetics, Czech Academy of Sciences, Prague, Czech Republic, ${ }^{3}$ Institute of Physiology, Czech Academy of Sciences, Prague, Czech Republic, ${ }^{4}$ Institute for the Care of the Mother and Child, Third Faculty of Medicine, Charles University, Prague, Czech Republic, ${ }^{5}$ Center for Experimental Medicine, Institute for Clinical and Experimental Medicine, Prague, Czech Republic

Received July 10, 2016

Accepted July 12, 2016

On-line October 26, 2016

\section{Summary}

We assessed the effect of the previously uncovered gap junction protein alpha 8 (Gja8) mutation present in spontaneously hypertensive rat - dominant cataract (SHR-Dca) strain on blood pressure, metabolic profile, and heart and renal transcriptomes. Adult, standard chow-fed male rats of SHR and SHR-Dca strains were used. We found a significant, consistent $10-15 \mathrm{mmHg}$ decrease in both systolic and diastolic blood pressures in SHR-Dca compared with SHR $(\mathrm{P}<0.01$ and $\mathrm{P}<0.05$, respectively; repeated measures analysis of variance (ANOVA)). With immunohistochemistry, we were able to localize Gja8 in heart, kidney, aorta, liver, and lungs, mostly in endothelium; with no differences in expression between strains. SHR-Dca rats showed decreased body weight, high-density lipoprotein cholesterol concentrations and basal insulin sensitivity in muscle. There were 21 transcripts common to the sets of 303 transcripts in kidney and 487 in heart showing $>1.2$-fold difference in expression between SHR and SHR-Dca. Tumor necrosis factor was the most significant upstream regulator and glial cell-derived neurotrophic factor family ligand-receptor interactions was the common enriched and downregulated canonical pathway both in heart and kidney of SHR-Dca. The connexin 50 mutation L7Q lowers blood pressure in the SHR-Dca strain, decreases high-density lipoprotein cholesterol, and leads to substantial transcriptome changes in heart and kidney.

\section{Key words}

Connexin • Hypertension • Transcriptome • Animal models • Insulin resistance

\section{Corresponding author}

O. Šeda, Institute of Biology and Medical Genetics, First Faculty of Medicine, Charles University, Albertov 4, 12800 Prague, Czech Republic. Fax: +420-224918666. E-mail: oseda@lf1.cuni.cz

\section{Introduction}

Hypertension has a high prevalence globally and represents a major risk factor for coronary heart disease, kidney failure, and stroke (Mozaffarian et al. 2016). Elucidation of the genes responsible for essential hypertension is, compared with other complex diseases, particularly challenging in spite of rather promising results stemming from recent large scale genome- wide association and exome sequencing studies (Padmanabhan et al. 2015). The identified genetic risk variants explain a relatively small portion of blood pressure variations, and therefore their clinical use remains limited.

Genetically defined animal models remain valuable tools for the identification of genes and pathways underlying complex cardiovascular traits, even in the era of systems biology (Civelek and Lusis 2014). The spontaneously hypertensive rat (SHR) is the 
most widely studied animal model of essential hypertension and has proven to be a highly valuable tool for deciphering the genomic, epigenomic, and physiological aspects of blood pressure control (Pravenec et al. 2014).

We previously identified a new connexin 50 mutation, L7Q (Liska et al. 2008), that arose spontaneously in the SHR/OlaIpcr (Rat Genome Database (RGD) ID: 631848; (Shimoyama et al. 2015) inbred rat leading to microphthalmia and cataract formation in thus created coisogenic rat strain SHR-Gja $8^{\mathrm{m} 1 \mathrm{Cub}}$ (SHR-Dca; RGD ID: 2293729).

Connexins are a family of transmembrane proteins that form intercellular gap junction channels. The family comprises 21 isoforms in rodents and humans (Saez and Leybaert 2014). There is considerable homology between the different connexins in humans, rats, and mice (Oyamada et al. 2005).

Several human genetic disorders caused by spontaneous mutations in connexin genes (Kelly et al. 2015) as well as knockout mouse disease models have been described to date (Reaume et al. 1995, White et al. 1998). Besides the lens of the eye as its major expression site (Beyer and Berthoud 2014), connexin 50 was also found to be present in mouse and rabbit retinae (O'Brien et al. 2006), in human and rat kidney (Silverstein et al. 2003), in rat cornea (Laux-Fenton et al. 2003), and in chromaffin cells of human adrenals (Willenberg et al. 2006).

In the present study, we used the coisogenic pair of rat inbred strains SHR and SHR-Dca, differing only in the identified point mutation (Liska et al. 2008), to examine the impact of connexin 50 on hemodynamic and metabolic parameters that make the SHR strain an experimental model of essential hypertension (Okamoto and Aoki 1963) and, in a broader sense, of metabolic syndrome (Pravenec et al. 2014).

\section{Methods}

\section{Ethical statement}

The study was conducted in accordance with the Animal Protection Law of the Czech Republic and was approved by the ethical committee of the First Faculty of Medicine, Charles University in Prague. Animals were held under temperature and humidity controlled conditions on a 12-h light/dark cycle. At all times, the animals had free access to food and water.

\section{Rat strains}

The SHR (RGD ID: 631848) is one of the most widely used models of essential hypertension (Langley et al. 2013) and disturbances of carbohydrate and lipid metabolism (Aitman et al. 1997). The SHR inbred colony in Prague was originally obtained from the US National Institutes of Health over 30 years ago, and since then it has been maintained by brother $\times$ sister mating at the Institute of Biology and Medical Genetics. SHR-Dca (RGD ID: 2293729) originated from a spontaneous mutation within our inbred SHR/OlaIpcv colony (Liska et al. 2008) and has been maintained at the Institute of Biology and Medical Genetics since.

\section{Metabolic measurements}

Adult, standard chow-fed males (4 months of age) of both strains ( $\mathrm{n}=8$ and $\mathrm{n}=9$ for SHR and SHR-Dca, respectively) were used for metabolic measurements. The oral glucose tolerance test was performed after an overnight fast and the blood samples taken for glycemic determination (Ascensia Elite Blood Glucose Meter; Bayer HealthCare, Mishawaka, IN, USA; validated by Institute of Clinical Biochemistry and Laboratory Diagnostics of the First Faculty of Medicine) were obtained from the tail vein at intervals of $0,30,60,120$, and $180 \mathrm{~min}$ after the intragastric glucose administration to conscious rats ( $3 \mathrm{~g} / \mathrm{kg}$ body weight, $30 \%$ aqueous solution). The lipidemic profile (cholesterol and triacylglycerol blood concentrations in 20 lipoprotein fractions, glycerol level, and chylomicron, very-low-density lipoprotein (VLDL), low-density lipoprotein (LDL), and high-density lipoprotein (HDL) particle sizes) was assessed using high performance liquid chromatography, as described previously (Sedova et al. 2012, Usui et al. 2002). For determination of triacylglycerol content in the liver, tissue was powdered under liquid $\mathrm{N}_{2}$ and extracted over $16 \mathrm{~h}$ in chloroform:methanol after which $2 \% \mathrm{KH}_{2} \mathrm{PO}_{4}$ was added and the solution centrifuged. The organic phase was removed and evaporated under $\mathrm{N}_{2}$. The resulting pellet was dissolved in isopropyl alcohol, and the triacylglycerols content was determined by enzymatic assay (ErbaLachema, Brno, Czech Republic).

Basal- and insulin-stimulated glycogen synthesis in muscle, and glucose utilization in isolated white adipose tissue

Diaphragmatic muscles were incubated ex vivo for $2 \mathrm{~h}$ in $95 \% \mathrm{O}_{2}+5 \% \mathrm{CO}_{2}$ in Krebs-Ringer bicarbonate buffer, (pH 7.4) containing $0.1 \mu \mathrm{Ci} / \mathrm{ml}$ of $\left[\mathrm{U}_{-}{ }^{14} \mathrm{C}\right]$ glucose, 
$5 \mathrm{mmol} / \mathrm{l}$ of unlabeled glucose, and $2.5 \mathrm{mg} / \mathrm{ml}$ of bovine serum albumin (Fraction V; Sigma-Aldrich, St. Louis, MO, USA), with or without $250 \mu \mathrm{U} / \mathrm{ml}$ insulin. Glycogen was extracted, and insulin stimulated incorporation of glucose into glycogen was determined. Pieces of epididymal fat were rapidly dissected and incubated for $2 \mathrm{~h}$ in Krebs-Ringer bicarbonate buffer with $5 \mathrm{mmol} / 1$ glucose, $0.1 \mu \mathrm{Ci}\left[\mathrm{U}-{ }^{14} \mathrm{C}\right]$ glucose/ml (UVVR, Prague, Czech Republic) and $2 \%$ bovine serum albumin, gaseous phase $95 \% \mathrm{O}_{2}$ and $5 \% \mathrm{CO}_{2}$ in the presence $(250 \mu \mathrm{U} / \mathrm{ml})$ or absence of insulin in incubation media. All incubations were performed at $37^{\circ} \mathrm{C}$ in sealed vials in a shaking water bath. We estimated incorporation of $\left[\mathrm{U}-{ }^{14} \mathrm{C}\right]$ glucose into neutral lipids. Briefly, fat was removed from incubation medium, rinsed in saline, and immediately placed into chloroform. Pieces of tissue were dissolved using a Teflon pestle homogenizer, methanol was added (chloroform:methanol 2:1), and lipids were extracted at $4{ }^{\circ} \mathrm{C}$ overnight. The remaining tissue was removed, $\mathrm{KH}_{2} \mathrm{PO}_{4}$ was added, and the clear extract was taken for further analysis. An aliquot was evaporated, reconstituted in scintillation liquid, and radioactivity measured by scintillation counting. Incremental glucose utilization was calculated as the difference between the insulin-stimulated and basal incorporation of glucose into neutral lipids.

\section{Blood pressure measurement}

This was performed using a group of animals distinct to those used for metabolic studies. Rats were fed standard chow and had free access to food and water. Arterial blood pressure was measured continuously by radiotelemetry in conscious, unrestrained 12-week-old male rats ( $\mathrm{n}=8$ for each strain). All rats were allowed to recover for at least 7 days after surgical implantation of radiotelemetry transducers before the start of blood pressure recordings. Pulsatile pressure was recorded in 10 -second bursts every $10 \mathrm{~min}$ throughout the day, and 12-hour averages for systolic and diastolic arterial blood pressure were calculated for each rat for a period of 21 days. Results from each rat in the same group were averaged to obtain the group mean.

\section{Immunohistochemistry}

At the end of the experiments, the left kidney, heart, aorta, vena cava inferior, liver, lungs, and testes were quickly removed and snap frozen in liquid $\mathrm{N}_{2}$. Threemicrometer-thick cryostat sections were used for immunohistochemistry. Slides were fixed in $4 \%$ paraformaldehyde for $2 \mathrm{~min}$ at $4{ }^{\circ} \mathrm{C}$. Sections were immunostained with polyclonal rabbit connexin 50 antibody (Santa Cruz, Dallas, USA) diluted 1:500 in ChemMate antibody diluent (Dako, Cytomation, Glostrup, Denmark). Primary antibody was performed overnight at $4{ }^{\circ} \mathrm{C}$. An Envision kit (Dako, Cytomation, Glostrup, Denmark) was used to visualize sections incubated with the primary antibody. Chromogen 3,3-diaminobenzidine was applied to all sections and counterstaining was performed with Mayer's hematoxylin. Optimal staining conditions of any given antibody were determined using appropriate positive and negative controls. Slides were analyzed on a Nikon ECLIPSE Ni-E (Nikon, Tokyo, Japan). All immunostainings were confirmed using at least five rats in each group.

\section{Glomerular size assessment}

Right kidney and parts of other organs (heart, aorta, vena cava inferior, liver, lungs, and testes) were fixed in $4 \%$ buffered formaldehyde, dehydrated, and embedded. Five-micrometer-thick paraffin sections were stained with hematoxylin/eosin and periodic acid-Schiff reaction and examined using a Nikon ECLIPSE Ni-E light microscope (Nikon). Slides were evaluated in a blind fashion.

Morphometric evaluation of glomerular volume was made with the same kidney sections that were examined for morphological changes using the method validated by Lane et al. (1992) and employed in our recent studies (Certikova Chabova et al. 2010) using Nikon NIS-Elements AR 3.1 morphometric program (Nikon). Briefly, this method involves determination of mean glomerular profile area and calculation of mean glomerular volume from the following formula: glomerular volume $=$ $\operatorname{area}^{1.5} \times 1.38 / 1.01$, where 1.38 is $\beta$, the shape coefficient for a sphere, and 1.01 is the size distribution coefficient 0 assuming a $10 \%$ coefficient of variation.

Transcriptomic profiling and quantitative real-time polymerase chain reaction (PCR)

Affymetrix GeneChip ${ }^{\circledR}$ Rat Exon 1.0 ST array was used to determine transcriptomic characteristics of SHR and coisogenic strain SHR-Dca. We extracted total RNA from the kidneys and hearts of 4-month-old males of both strains ( $\mathrm{n}=6$ per strain) using phenol-chloroform and purified using a RNeasy Mini kit (Qiagen, Valencia, CA, USA) in accordance with the manufacturer's protocol. The quality of total RNA was verified using an Agilent 2100 Bioanalyzer system. Double-stranded complementary DNA (cDNA) was synthesized from total RNA. Labeled 
and fragmented cDNA was pooled for each strain (SHR, SHR-Dca) and tissue (heart, kidney) and hybridized to Affymetrix GeneChip ${ }^{\circledR}$ Rat Exon 1.0 ST arrays in triplicate (three pools per strain and tissue, each containing RNA from two animals, i.e. a total of 12 arrays). The whole hybridization procedure including DNA adjustment was performed according to the protocol recommended by Affymetrix. The microarray data were deposited in ArrayExpress database (www.ebi.ac.uk/arrayexpress) under accession number E-MTAB-4542. To validate microarray gene expression data, quantitative real-time PCR (SYBR-Green) was used. Total RNA $(2 \mu \mathrm{g})$ was reverse-transcribed with random primers using a SuperScript ${ }^{\circledR}$ VILO $^{\mathrm{TM}}$ cDNA synthesis kit (Invitrogen, Carlsbad, CA, USA). Primers were designed using Primer3 (Untergasser et al. 2012) and synthesized by Integrated DNA Technologies (Coralville, IA, USA). Real-time PCR was performed in quadruplicate with EXPRESS SYBR ${ }^{\circledR}$ GreenER $^{\text {TM }}$ qPCR SuperMix with a Premixed ROX kit according to the manufacturer's protocol (Invitrogen) using an Applied Biosystems 7900HT Fast real-time PCR System. Results were analyzed using the Pfaffl analysis method (Pfaffl, 2001) with the reference genes peptidylprolyl isomerase $\mathrm{B}$ and $18 \mathrm{~S}$.

\section{Statistical and pathway analyses}

Metabolic and morphometric data were compared using the unpaired Student's $t$-test. For transcriptomic data, after evaluation of hybridization, quality control, and the data normalization by robust multi-array analysis, gene expression was compared between the SHR and the SHR-Dca strains using PARTEK Genomics Suite 6.6 (Partek, Inc., Chesterfield, MO, USA). Transcripts found to be significantly differentially expressed by more than 1.2-fold between the two strains after multiple comparison adjustment using the false discovery rate method $(\mathrm{FDR}<0.05)$ were included in gene enrichment and pathway analyses, which were performed using Ingenuity Pathway Analysis software (application build $364062 \mathrm{M}$, content version 26127183) as described previously (Krupkova et al. 2014, Sedova et al. 2012).

\section{Results}

\section{Morphometry and basic metabolic profile}

SHR-Dca rats weighted about $50 \mathrm{~g}$ less than SHR (Table 1). Relative weights of visceral fat pad, kidney, and adrenals were significantly greater in SHR-Dca rats compared with SHR (Table 1). Concentrations of fasting plasma glucose, insulin, leptin, adiponectin, and free glycerol as well as the liver triacylglycerol concentration were also comparable between SHR and SHR-Dca (Table 2). Fasting glucose concentrations as well as the courses of glycemic curves during the oral glucose tolerance test were nearly identical.

\section{Detailed lipid profile}

The distribution of triacylglycerols and cholesterol across major lipoprotein fractions followed a similar pattern in both strains except for HDL cholesterol concentrations, which were significantly lower in SHR-Dca compared with SHR (Table 2). As shown in Fig. 1A, this difference was driven by distinct cholesterol content within very large and large HDL particles. Detailed comparison of triacylglycerol content in 20 lipoprotein fractions did not reveal any additional differences between SHR and SHR-Dca (Fig. 1B) nor in respective sizes of lipoprotein particles: VLDL $45.02 \pm 0.58$ vs. $46.28 \pm 0.19 \mathrm{~nm}$; LDL $20.93 \pm 0.13$ vs. $21.34 \pm 0.45 \mathrm{~nm}$; HDL $12.37 \pm 0.02$ vs. $12.30 \pm 0.05 \mathrm{~nm}$ in SHR vs. SHR-Dca, respectively ( $\mathrm{P}>0.05$ in all comparisons).

Table 1. Morphometric comparison between SHR and SHR-Dca rats.

\begin{tabular}{lccc}
\hline Trait & SHR $(\mathbf{n}=\mathbf{8})$ & SHR-Dca $(\mathbf{n}=\mathbf{9})$ & $\mathbf{P}_{\text {t-test }}$ \\
\hline Body weight, $g$ & $350 \pm 20$ & $299 \pm 12$ & 0.049 \\
Liver, g/100 g body weight & $3.19 \pm 0.10$ & $3.53 \pm 0.29$ & 0.35 \\
Heart, g/100 g body weight & $0.44 \pm 0.04$ & $0.47 \pm 0.02$ & 0.52 \\
Kidney, g/100 g body weight & $0.71 \pm 0.02$ & $0.82 \pm 0.03$ & 0.028 \\
Adrenals, g/100 g body weight & $0.010 \pm 0.001$ & $0.013 \pm 0.001$ & 0.042 \\
EFP, g/100 g body weight & $1.04 \pm 0.05$ & $1.28 \pm 0.09$ & 0.027 \\
RFP, g/100 g body weight & $1.84 \pm 0.30$ & $1.39 \pm 0.09$ & 0.16 \\
\hline
\end{tabular}

Data are expressed as mean \pm standard error of mean (S.E.M.). b.wt: body weight; EFP: epididymal fat pad; RFP: retroperitoneal fat pad. Significance levels of inter-strain comparisons between SHR and SHR-Dca strains are shown in the last column. 
Table 2. Metabolic comparison between SHR and SHR-Dca male rats.

\begin{tabular}{lccc}
\hline Trait & SHR $(\mathbf{n}=\mathbf{8})$ & SHR-Dca $(\mathbf{n}=\mathbf{9})$ & $\mathbf{P}_{\text {t-test }}$ \\
\hline Glucose $(\mathrm{mg} / \mathrm{dl})$ & $74.9 \pm 1.8$ & $73.3 \pm 3.9$ & 0.76 \\
Insulin $(\mathrm{ng} / \mathrm{ml})$ & $1.75 \pm 0.28$ & $1.54 \pm 0.49$ & 0.87 \\
Leptin $(\mathrm{ng} / \mathrm{ml})$ & $0.17 \pm 0.03$ & $0.26 \pm 0.03$ & 0.10 \\
Adiponectin $(\mu \mathrm{g} / \mathrm{ml})$ & $6.03 \pm 0.03$ & $5.93 \pm 0.03$ & 0.10 \\
Glycerol $(\mathrm{mg} / \mathrm{dl})$ & $2.55 \pm 0.23$ & $1.86 \pm 0.33$ & 0.16 \\
Liver TG $(\mu \mathrm{mol} / \mathrm{g})$ & $11.2 \pm 0.8$ & $11.7 \pm 0.9$ & 0.70 \\
Cholesterol $(\mathrm{mg} / \mathrm{dl})$ & & & \\
Total C & $41.52 \pm 1.85$ & $37.65 \pm 0.87$ & 0.13 \\
Chylomicron C & $0.10 \pm 0.01$ & $0.10 \pm 0.02$ & 0.97 \\
VLDL-C & $0.73 \pm 0.04$ & $0.86 \pm 0.18$ & 0.52 \\
LDL-C & $8.75 \pm 0.93$ & $10.01 \pm 1.96$ & 0.59 \\
HDL-C & $31.94 \pm 0.91$ & $26.68 \pm 1.51$ & 0.041 \\
Triacylglycerols $(\mathrm{mg} / \mathrm{dl})$ & & & \\
Total TG & & $17.70 \pm 1.94$ & 0.97 \\
Chylomicron TG & $17.54 \pm 2.99$ & $0.57 \pm 0.07$ & 0.85 \\
VLDL-TG & $0.61 \pm 0.16$ & $4.17 \pm 0.44$ & 0.73 \\
LDL-TG & $3.95 \pm 0.44$ & $9.71 \pm 2.16$ & 0.97 \\
HDL-TG & $9.81 \pm 1.29$ & $3.08 \pm 0.33$ & 0.70 \\
\hline
\end{tabular}

Data are expressed as mean \pm S.E.M. C: cholesterol; TG: triacylglycerols; VLDL: very-low-density lipoprotein, LDL: low-density lipoprotein; HDL: high-density lipoprotein. Significance levels of inter-strain comparisons between SHR and SHR-Dca strains are shown in the last column.

\section{Blood pressure measurements}

Throughout the 21-day period of measurement, SHR-Dca male rats showed significantly lower systolic $(\mathrm{P}<0.01$; repeated measures ANOVA) and diastolic blood pressures $(\mathrm{P}<0.05$; repeated measures ANOVA) compared with SHR (Fig. 2). We observed similar differences in 6-months-old animals (data not shown). Heart rate comparison did not yield significant differences between the two strains throughout the whole period of measurement.

\section{Insulin sensitivity of muscle and adipose tissues}

Insulin sensitivity of visceral adipose tissue did not differ between SHR and SHR-Dca (Fig. 3A). We observed reduced basal glycogenesis in muscles of SHR-Dca, but insulin-stimulated glycogenesis values were comparable between the strains (Fig. 3B).

\section{Immunohistochemical assessment of GJA8 tissue distribution}

There were no differences in GJA8 expression or distribution between SHR and SHR-Dca. We were able to identify the presence of GJA8 in endothelium of large vessels including the aorta and vena cava, and in endothelium of capillaries in heart, lungs, liver, and kidneys. In glomeruli and pre-glomerular and peritubular capillaries, no staining was apparent in tubules (Fig. 4). The basal membrane of the tubuli seminiferi in testes was also slightly positive. There were no morphological changes in renal parenchyma. The glomerular volume of SHR was significantly greater than that of SHR-Dca rats $(4.44 \pm 0.25$ vs. $\left.3.39 \pm 0.28 \times 10^{6} \mu \mathrm{m}^{3}, \mathrm{P}=0.013\right)$.

\section{Heart and kidney transcriptome analysis}

In heart, there were 303 transcripts showing $>1.2$-fold difference in expression between SHR and SHR-Dca, with 151 relatively upregulated and 152 downregulated in microphthalmic rats. The most enriched functional categories were related to cell development (Benjamini-Hochberg multiple testing correction; $\mathrm{P}=1.67 \times 10^{-4}$ ), growth and proliferation $\left(\mathrm{P}=3.51 \times 10^{-4}\right)$, including the most significantly upregulated (S100A9, Csf $3 r, S 100 A 8, B c l 6)$ and downregulated (Nr4a1, Fos, Egr1, Dusp1, Cyr61) genes in SHR-Dca compared with SHR. 


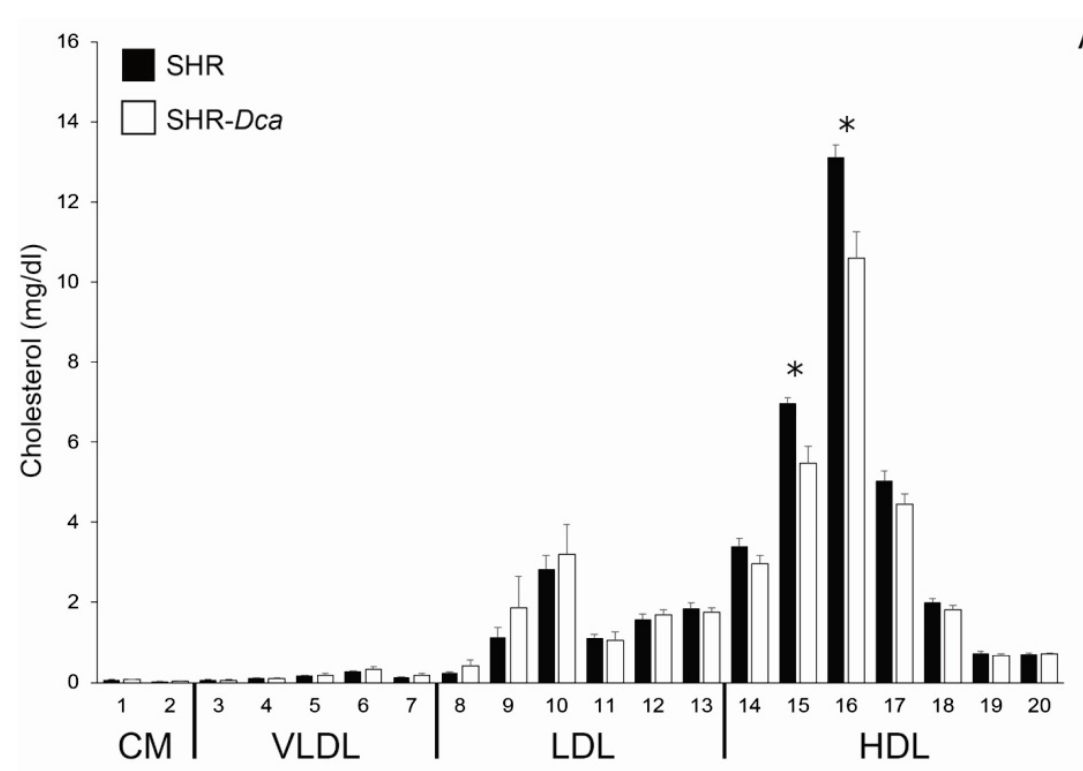

B
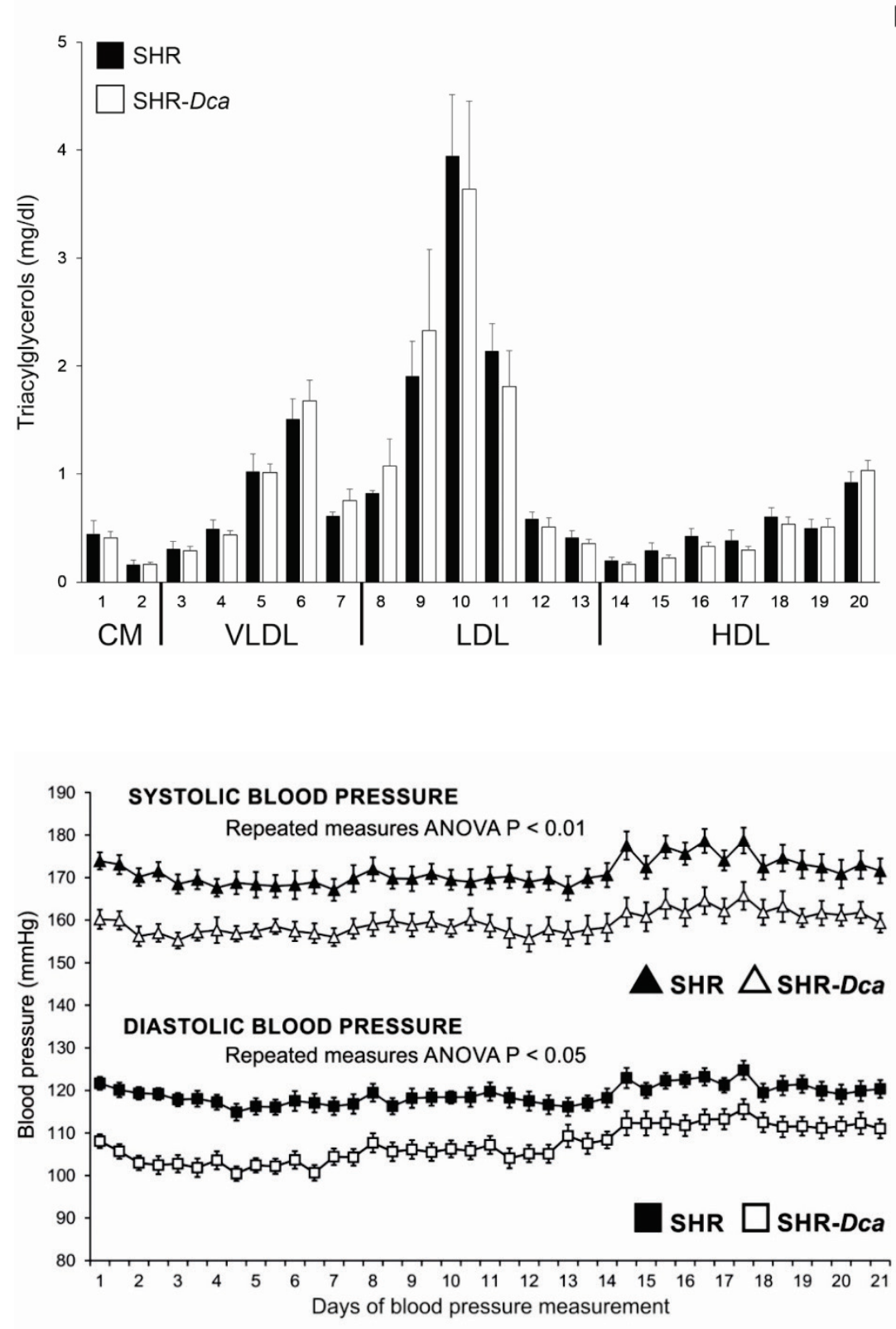

Fig. 1. Cholesterol (A) and triacylglycerols (B) content in 20 lipoprotein subfractions in standard diet-fed SHR (closed symbols) vs. SHR-Dca (open symbols) male rats. Within the graph, the adjusted significance levels of strain comparisons using the unpaired $t$-test are indicated as $* \mathrm{P}<0.05$. Data are expressed as mean \pm S.E.M. ( $n=8-9 /$ group). The allocation of individual lipoprotein subfractions to major lipoprotein classes is shown in order of decreasing size of particles from left to right. CM: chylomicron; VLDL: very-low-density lipoprotein; LDL: low-density lipoprotein; HDL: high-density lipoprotein. 

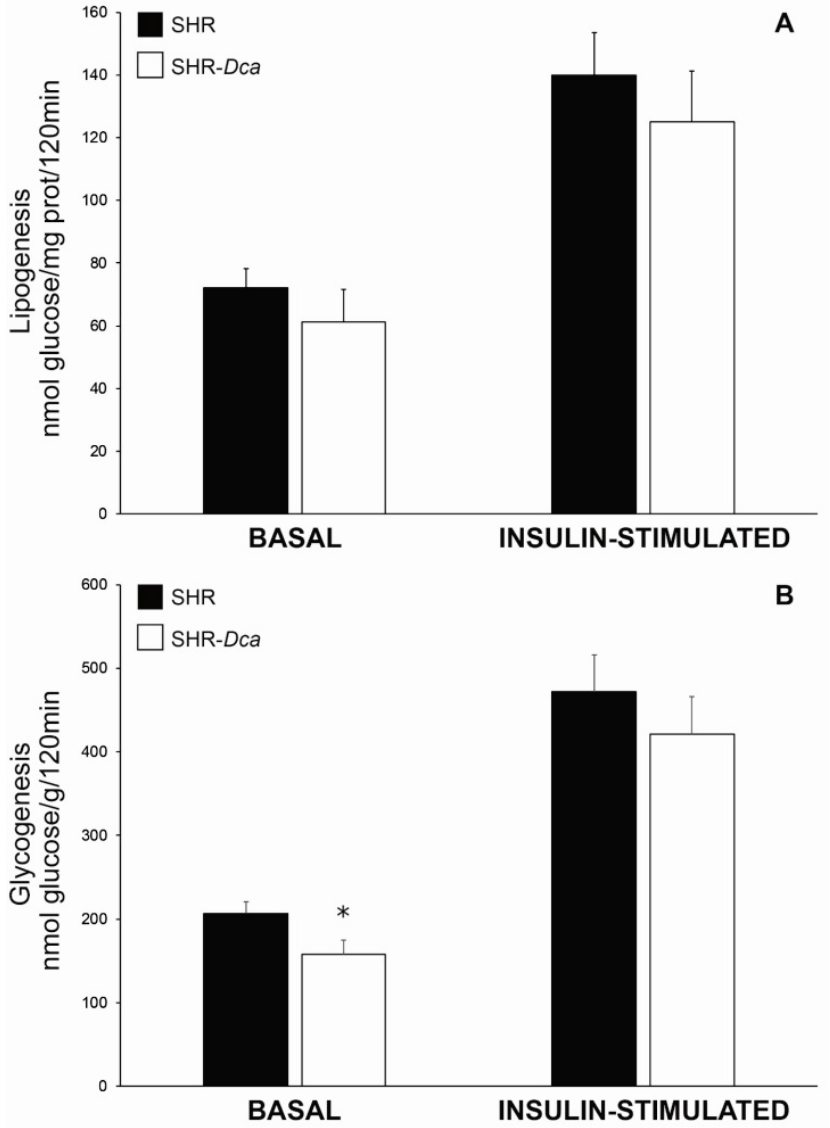

Fig. 3. Insulin sensitivity of peripheral tissues in SHR and SHR-Dca male rats. Basal- and insulin-stimulated $\left[\mathrm{U}-{ }^{14} \mathrm{C}\right]$ glucose incorporation into glycogen of the diaphragm and into total lipids of epididymal (visceral) adipose tissue are shown. Data are expressed as mean \pm S.E.M. ( $n=8 /$ group). Adjusted statistical significance levels using the unpaired $t$-test are indicated as $* \mathrm{P}<0.05$.

Among "tox lists" (i.e. lists linked to clinical pathology endpoints), cardiac fibrosis and cardiac hypertrophy reached significant enrichment $\left(\mathrm{P}=7.47 \times 10^{-4}\right.$ and $9.9 \times 10^{-3}$, respectively).

There were three significantly over-represented canonical pathways, all of them predicted to be inhibited in SHR-Dca: the integrin linked kinase pathway $\left(\mathrm{P}=8.64 \times 10^{-3}\right)$, glial cell-derived neurotrophic factor family (GDNF) ligand-receptor interactions $\left(\mathrm{P}=1.26 \times 10^{-2}\right)$ and production of nitric oxide and reactive oxygen species in macrophages $\left(\mathrm{P}=4.70 \times 10^{-2}\right)$. Upstream regulator analysis revealed the tumor necrosis factor family $\left(\mathrm{P}=8.75 \times 10^{-14}\right)$, interleukin 1 beta $\left(\mathrm{P}=6.24 \times 10^{-11}\right)$, and interleukin $17 \mathrm{~A}\left(\mathrm{P}=9.08 \times 10^{-10}\right)$ to be the top predicted upstream transcriptional regulators that can explain the observed gene expression changes in SHR-Dca vs. SHR hearts.

In the kidney, there were 487 transcripts showing $>1.2$-fold difference in expression between SHR and SHR-Dca, with 254 relatively upregulated and 233 downregulated in the microphthalmic rats. There were 21 transcripts common to the heart and kidney sets (Table 3).

We confirmed direction of expression changes between SHR and SHR-Dca by qPCR. Using all significantly differentially expressed genes, we systematically assessed their enrichment in ontological categories or disease-related gene sets as well as their potential functional connections. Gene set enrichment analysis revealed similar patterns as in the heart, with cellular growth and proliferation being the most enriched category $\left(\mathrm{P}=6.09 \times 10^{-9}\right)$. Interestingly, we observed concerted downregulation of cholesterol synthesis genes Dhcr7, Hmgcr, and Sqle, rendering the cholesterol biosynthesis the only significantly enriched tox list. The top predicted upstream transcriptional regulators in the kidney were colony stimulating factor $3\left(\mathrm{P}=1.79 \times 10^{-10}\right)$, tumor necrosis factor family $\left(\mathrm{P}=3.42 \times 10^{-10}\right)$, and inhibitor of DNA binding $3\left(\mathrm{P}=4.60 \times 10^{-9}\right)$.

Corresponding to findings in the heart, the canonical pathway of glial cell-derived neurotrophic factor family ligand-receptor interactions was significantly enriched $\left(\mathrm{P}=4.14 \times 10^{-2}\right)$ and predicted to be inhibited in the kidney. The second enriched pathway was the role of macrophages, fibroblasts, and endothelial cells in rheumatoid arthritis $\left(\mathrm{P}=1.22 \times 10^{-2}\right)$. We assessed potential functional relationships among genes differentially expressed between SHR and SHR-Dca both in the kidney and heart using dynamic pathway modeling. Both approaches focused on direct interactions of identified genes or the "shortest path" among them and revealed a network of tightly interconnected genes likely to represent the major module behind the Gja8-induced transcriptome shift (Fig. 5).

\section{Discussion}

Conditions such as hypertension or diabetes have been previously associated with changes in regulation and expression of connexins 37, 40, 43, and 45 in a variety of tissues including heart (Meens et al. 2013), lungs (Kim et al. 2015), vasculature (Morton et al. 2015), kidneys (Gerl et al. 2015), and islets of Langerhans (Farnsworth and Benninger 2014). To date, connexin 50 has been almost exclusively associated with lens development (Berthoud et al. 2014). 

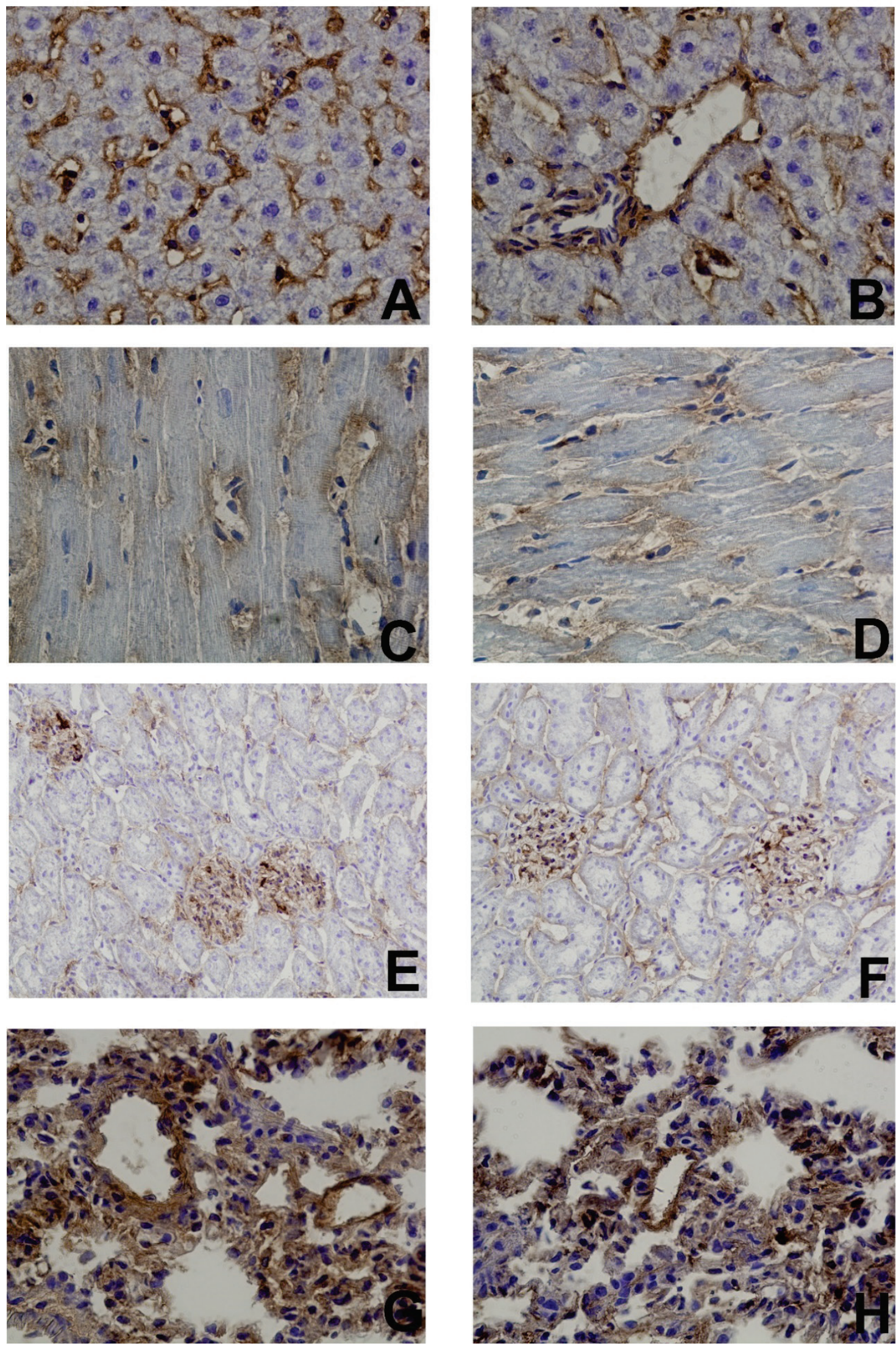

Fig. 4. Immunohistochemical staining of connexin 50 (CX50, GJA8) in endothelial cells of SHR and SHR-Dca rats. (A) SHR liver parenchyma, CX50 expression in sinusoids 400x; (B) SHR-Dca liver parenchyma, CX50 expression in central vein and sinusoids 400×; (C, D) Heart of SHR (C) and SHR-Dca (D) with positive capillaries 400x; (E, F) Kidney of SHR (E) and SHR-Dca (F). Positive endothelial cells are seen in the glomerular capillaries, preglomerular and peritubular capillary vessels, tubules are negative 200×; (G, H) Lungs of SHR (G) and SHR-DCa (H), strong CX50 expression within capillaries 400×. 
Table 3. Genes significantly differentially expressed between SHR-Dca and SHR in both heart and kidney.

\begin{tabular}{|c|c|c|c|c|c|}
\hline Symbol & Gene Name & $\begin{array}{l}\text { P-value } \\
\text { (Heart) }\end{array}$ & $\begin{array}{l}\text { Fold Change } \\
\text { (Heart) }\end{array}$ & $\begin{array}{l}\text { P-value } \\
\text { (Kidney) }\end{array}$ & $\begin{array}{c}\text { Fold } \\
\text { Change } \\
\text { (Kidney) }\end{array}$ \\
\hline Duspl & Dual specificity phosphatase 1 & $1.95 \mathrm{E}-02$ & -1.96 & $6.27 \mathrm{E}-03$ & -1.39 \\
\hline Cyr61 & Cysteine-rich, angiogenic inducer 61 & 4.12E-04 & -1.56 & $1.67 \mathrm{E}-03$ & -2.46 \\
\hline Frs 2 & Fibroblast growth factor receptor substrate 2 & $1.02 \mathrm{E}-02$ & -1.52 & $1.18 \mathrm{E}-02$ & -1.43 \\
\hline Rnd3 & Rho family GTPase 3 & $1.16 \mathrm{E}-02$ & -1.22 & $4.01 \mathrm{E}-03$ & -1.35 \\
\hline $\operatorname{Rgs} 2$ & Regulator of G-protein signaling 2 & $3.58 \mathrm{E}-02$ & -1.36 & $1.96 \mathrm{E}-02$ & 1.24 \\
\hline Prkg1 & Protein kinase, cGMP-dependent, type I & $3.41 \mathrm{E}-02$ & 1.26 & 2.19E-04 & -1.23 \\
\hline Tmem82 & Transmembrane protein 82 & 4.12E-02 & 1.27 & $9.73 \mathrm{E}-03$ & -1.27 \\
\hline Cep95 & Centrosomal protein $95 \mathrm{kDa}$ & 4.33E-02 & 1.22 & 5.70E-04 & 1.21 \\
\hline March1 & $\begin{array}{l}\text { Membrane-associated ring finger membrane- } \\
\text { associated ring-CH-type finger } 1\end{array}$ & 2.91E-03 & 1.24 & $2.03 \mathrm{E}-02$ & 1.33 \\
\hline Let-7 & MicroRNA let-7a-1 & $1.15 \mathrm{E}-02$ & 1.30 & $1.55 \mathrm{E}-02$ & 1.23 \\
\hline Arrdc3 & Arrestin domain containing 3 & 3.37E-02 & 1.31 & $1.69 \mathrm{E}-02$ & 1.38 \\
\hline Pik3ip1 & Phosphoinositide-3-kinase interacting protein 1 & $1.27 \mathrm{E}-04$ & 1.38 & $2.67 \mathrm{E}-03$ & 1.33 \\
\hline Mir-29 & MicroRNA 29a & $3.68 \mathrm{E}-02$ & 1.55 & 4.07E-02 & 1.38 \\
\hline Bcl6 & B-cell CLL/lymphoma 6 & 4.44E-03 & 1.56 & $1.20 \mathrm{E}-04$ & 2.70 \\
\hline Mir-628 & MicroRNA 628 & $1.74 \mathrm{E}-02$ & 1.75 & $1.95 \mathrm{E}-02$ & 1.33 \\
\hline Mir-23 & MicroRNA 23a & $6.46 \mathrm{E}-04$ & 1.77 & $6.44 \mathrm{E}-03$ & 1.43 \\
\hline Mir-27 & MicroRNA 27a & $1.15 \mathrm{E}-02$ & 1.81 & $6.04 \mathrm{E}-03$ & 1.40 \\
\hline Mir-30 & MicroRNA 30a & $2.93 \mathrm{E}-03$ & 2.14 & $1.92 \mathrm{E}-02$ & 1.34 \\
\hline Clec $4 d$ & C-type lectin domain family 4 , member D & $2.24 \mathrm{E}-03$ & 2.23 & $1.33 \mathrm{E}-02$ & 1.50 \\
\hline Mir-223 & MicroRNA 223 & $3.78 \mathrm{E}-02$ & 2.31 & $5.45 \mathrm{E}-03$ & 1.54 \\
\hline S100a9 & S100 calcium binding protein A9 & $1.15 \mathrm{E}-02$ & 3.61 & $1.80 \mathrm{E}-02$ & 1.59 \\
\hline
\end{tabular}

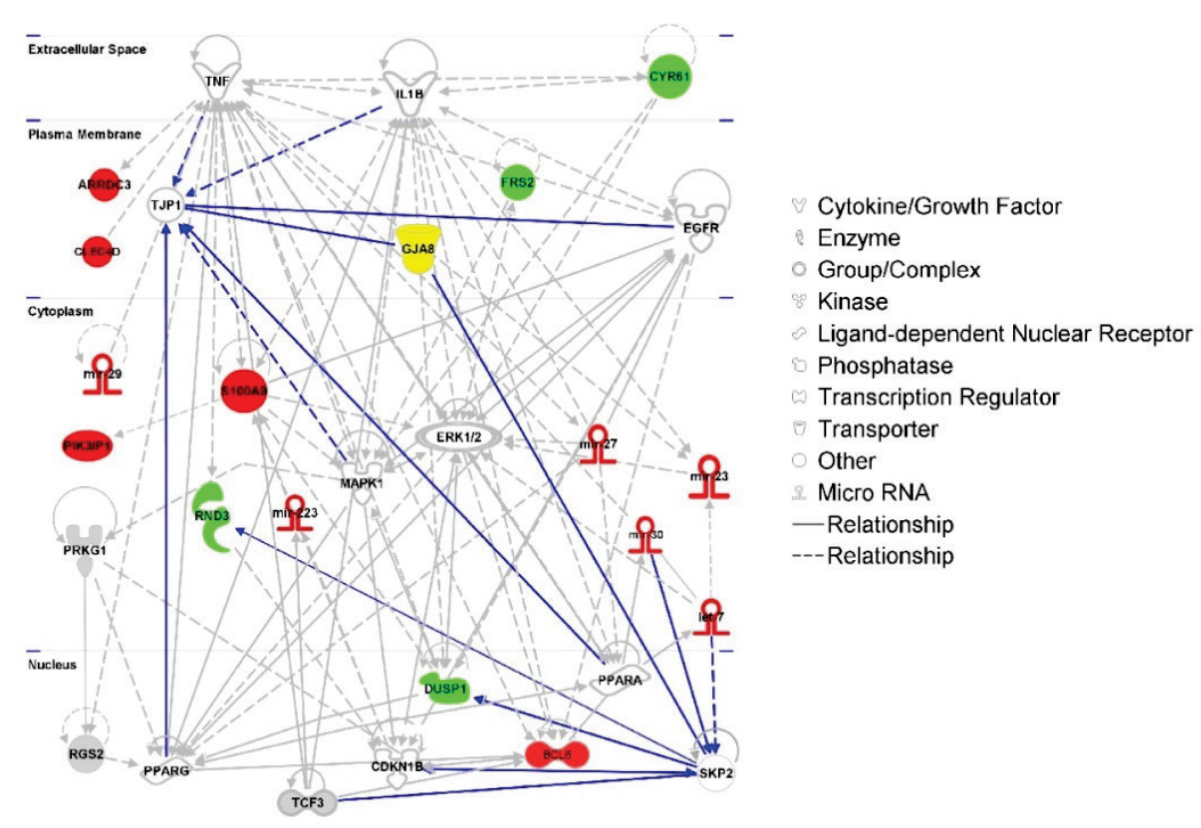

Fig. 5. Network analysis of the differentially expressed genes both in hearts and kidneys of SHR and SHR-Dca. The figure represents the network with the highest score (IPA, Ingenuity Systems) derived using the whole set of differentially expressed genes between SHR and SHR-Dca both in hearts and kidneys. Genes significantly downregulated in SHR-Dca compared with SHR in both hearts and kidneys are in red. Upregulated genes in SHR-Dca compared with SHR in both hearts and kidneys are in green. Grey shading denotes differential expression only in the heart or kidney. Blue lines represent known relationships between Gja8 and its closest neighbor members of the network. Grey lines denote known relationships among all the members of the network based on the Ingenuity Pathway Database. 
Gja8 mutations resulting in cataract and microphthalmia were described in mice (White et al. 1998), rats (Liska et al. 2008), and humans (Ge et al. 2014, Shiels et al. 1998). Interestingly, even transgenic overexpression of connexin 50 is reported to induce cataracts (Chung et al. 2007). However, Gja8 expression is not limited to the lens, as shown in several studies including the present one. Localization of connexin 50 in vascular endothelial cells follows the pattern of predominant connexins (Gabriels and Paul 1998).

Besides the previously described microphthalmia and cataract development in SHR-Dca rats (Liska et al. 2008), in the present study, we observed that a major effect of the L7Q mutation in the Gja8 gene was the lowering of blood pressure. In spite of the significant blood pressure decrease, the SHR-Dca rats still show values in hypertensive range. To date, several other connexins have been shown to modulate blood pressure in animal models. While Cx40-deficient mice are hypertensive, most likely because of renin cell displacement and defective pressure control of renin secretion, Cx37-knockout mice do not show changes in blood pressure (Figueroa and Duling 2008), and endothelial cell-specific knockout of $C x 43$ (which is also significantly expressed in the lens) was shown to cause hypotension and bradycardia in mice (Liao et al. 2001). We did not observe any morphological changes suggestive of cardiac hypertrophy or kidney damage in spite of established hypertension. This may be because of the younger age of the rats used; enlarged glomeruli in SHR might indicate one of the stepping stones towards secondary focal segmental glomerulosclerosis through mechanical damage to podocytes (Kriz 2002). Nevertheless, concerted expression changes in the heart suggest diverging paths between SHR and SHR-Dca, with a more favorable profile in Gja8-mutant rats.

Upregulation of several genes in SHR-Dca is indicative of a tendency towards decreased cardiac fibrosis including B-cell CLL/lymphoma 6, microRNAs miR-23, miR39, miR30, and let-7, nitric oxide synthase 3, cAMP responsive element binding protein 1 , and cannabinoid receptor 2 genes (Ingenuity Knowledge Base).

One of the limitations of the present study lies in the fact that we did not uncover the detailed mechanism that results in the lowering of blood pressure and other metabolic effects in the Gja8-mutant animals. Analyses of the most perturbed pathways suggests several possible routes affecting a number of genes with a previously ascertained role in cardiovascular pathology, like S100 calcium binding protein A9 (Zhao et al. 2011), Rho family GTPase 3 (Yue et al. 2016), fibroblast growth factor receptor substrate 2 (Turner et al. 2008), and cysteine-rich, angiogenic inducer 61 (Unoki et al. 2003) (Fig. 5). SHR-Dca rats carry the nonsynonymous mutation L7Q in the amino terminal domain of Cx50 (Liska et al. 2008). In a review of available structural and functional studies of Cx50 gap junction channels, Xin and Bai summarized compelling evidence that the amino terminal domain of $\mathrm{Cx} 50$ lines the pore of gap junction channels and plays an important role in single channel conductance and transjunctional voltage-dependent gating as well as in limiting the rate of ion permeation (Xin and Bai 2013). While we did not perform any functional studies, it is possible that the mutation in SHR-Dca's Cx50 changed its coupling properties resulting in altered vascular endothelial and smooth muscle cells communication.

We are aware that construction of mechanistic networks is based solely on available information on reported interactions between genes and their products; as such, it is inherently biased against the as yet uncharacterized or less annotated transcripts. Among the set of differentially expressed genes, we identified a number of microRNAs (11 and 15 in heart and kidney, respectively). The most upregulated microRNA in heart (and second most upregulated in kidney) of SHR-Dca compared with SHR was miR-223. Upregulation of miR-223 was found in the insulin-resistant human heart and its overexpression induced glucose transporter 4 protein expression (Lu et al. 2010). This finding seems to be consistent with the decreased basal insulin sensitivity of skeletal muscle tissue in SHR-Dca. Also, miR-223 was found to regulate HDL cholesterol uptake and to inhibit cholesterol biosynthesis (Vickers et al. 2014), again in line with findings from the comparison of the lipid profiles in the present study. Alternatively, downregulation of miR-223 in rat lungs is directly related to pathogenesis of the pulmonary artery hypertension (Meloche et al. 2015), and elevated circulating miR-223 is a predictive biomarker of coronary artery disease and cardiovascular death (Schulte et al. 2015).

Interestingly, the Gja8 gene is in an area of rat genome with numerous quantitative trait loci for blood pressure in SHR and other hypertensive rat models including Dahl salt-sensitive rat (Chauvet et al. 2013) or stroke-prone spontaneously hypertensive rat (Graham et al. 2007). Therefore, variation in Gjas gene might 
contribute to the respective QTLs, either acting alone or, in a modular, epistatic fashion (Chauvet et al. 2013, Koh-Tan et al. 2013). While it is unlikely that a second mutation (distinct from that in Gja8 gene) occurred in SHR-Dca and is responsible for the observed hemodynamic and metabolic effects, it cannot be ruled out absolutely. Potential genes of interest related to cardiovascular pathophysiology within the original interval that lead to identification of the causative Gja8 mutation include ATPase, $\mathrm{Na}+/ \mathrm{K}+$ transporting, alpha 1 polypeptide (Herrera et al. 2015, Orlov et al. 2001), gap junction protein alpha 5 (Schmidt et al. 2015), or thioredoxin-interacting protein (Yoshioka et al. 2012).

In summary, we found that connexin 50 is expressed in vascular endothelium of a number of tissues.
Mutation L7Q in connexin 50 lowers blood pressure in the SHR-Dca strain and decreases HDL cholesterol and basal insulin sensitivity in skeletal muscle of the SHR.

\section{Conflict of Interest}

There is no conflict of interest.

\section{Acknowledgements}

We are thankful to Gilles Corbeil for his valuable help with transcriptomic analyses. This work was supported by Czech Science Foundation Projects GAČR P301/12/0777 and P301/12/0696, Project LK11217 from the Ministry of Education, Youth and Sports of the Czech Republic, Charles University in Prague (PRVOUKP25/LF1/2, UNCE 204022).

\section{References}

AITMAN TJ, GOTODA T, EVANS AL, IMRIE H, HEATH KE, TREMBLING PM, TRUMAN H, WALLACE CA, RAHMAN A, DORE C, FLINT J, KREN V, ZIDEK V, KURTZ TW, PRAVENEC M, SCOTT J: Quantitative trait loci for cellular defects in glucose and fatty acid metabolism in hypertensive rats. Nat Genet 16: 197-201, 1997.

BERTHOUD VM, MINOGUE PJ, OSMOLAK P, SNABB JI, BEYER EC: Roles and regulation of lens epithelial cell connexins. FEBS Lett 588: 1297-1303, 2014.

BEYER EC, BERTHOUD VM: Connexin hemichannels in the lens. Front Physiol 5: 20, 2014.

CERTIKOVA CHABOVA V, WALKOWSKA A, KOMPANOWSKA-JEZIERSKA E, SADOWSKI J, KUJAL P, VERNEROVA Z, VANOURKOVA Z, KOPKAN L, KRAMER HJ, FALCK JR, IMIG JD, HAMMOCK BD, VANECKOVA I, CERVENKA L: Combined inhibition of 20-hydroxyeicosatetraenoic acid formation and of epoxyeicosatrienoic acids degradation attenuates hypertension and hypertension-induced end-organ damage in Ren-2 transgenic rats. Clin Sci (Lond) 118: 617-632, 2010.

CHAUVET C, CRESPO K, MENARD A, ROY J, DENG AY: Modularization and epistatic hierarchy determine homeostatic actions of multiple blood pressure quantitative trait loci. Hum Mol Genet 22: 4451-4459, 2013.

CHUNG J, BERTHOUD VM, NOVAK L, ZOLTOSKI R, HEILBRUNN B, MINOGUE PJ, LIU X, EBIHARA L, KUSZAK J, BEYER EC: Transgenic overexpression of connexin50 induces cataracts. Exp Eye Res 84: 513-528, 2007.

CIVELEK M, LUSIS AJ: Systems genetics approaches to understand complex traits. Nat Rev Genet 15: 34-48, 2014.

FARNSWORTH NL, BENNINGER RK: New insights into the role of connexins in pancreatic islet function and diabetes. FEBS Lett 588: 1278-87, 2014.

FIGUEROA XF, DULING BR: Dissection of two Cx37-independent conducted vasodilator mechanisms by deletion of Cx40: electrotonic versus regenerative conduction. Am J Physiol Heart Circ Physiol 295: H2001-H2007, 2008.

GABRIELS JE, PAUL DL: Connexin43 is highly localized to sites of disturbed flow in rat aortic endothelium but connexin37 and connexin40 are more uniformly distributed. Circ Res 83: 636-643, 1998.

GE XL, ZHANG Y, WU Y, LV J, ZHANG W, JIN ZB, QU J, GU F: Identification of a novel GJA8 (Cx50) point mutation causes human dominant congenital cataracts. Sci Rep 4: 4121, 2014.

GERL M, VOCKL J, KURT B, VAN VEEN TA, KURTZ A, WAGNER C: Inducible deletion of connexin 40 in adult mice causes hypertension and disrupts pressure control of renin secretion. Kidney Int 87: 557-563, 2015.

GRAHAM D, MCBRIDE MW, GAASENBEEK M, GILDAY K, BEATTIE E, MILLER WH, MCCLURE JD, POLKE JM, MONTEZANO A, TOUYZ RM, DOMINICZAK AF: Candidate genes that determine response to salt in the stroke-prone spontaneously hypertensive rat: congenic analysis. Hypertension 50: 1134-1141, 2007. 
HERRERA VL, PASION KA, MORAN AM, ZANINELLO R, ORTU MF, FRESU G, PIRAS DA, ARGIOLAS G, TROFFA C, GLORIOSO V, MASALA W, GLORIOSO N, RUIZ-OPAZO N: A functional 12T-insertion polymorphism in the ATP1A1 promoter confers decreased susceptibility to hypertension in a male Sardinian population. PLoS One 10: $\mathrm{e} 0116724,2015$.

KELLY JJ, SIMEK J, LAIRD DW: Mechanisms linking connexin mutations to human diseases. Cell Tissue Res 360: 701-721, 2015.

KiM J, HWANGBO C, HU X, KANG Y, PAPANGELI I, MEHROTRA D, PARK H, JU H, McLEAN DL, COMHAIR SA, ERZURUM SC, CHUN HJ: Restoration of impaired endothelial myocyte enhancer factor 2 function rescues pulmonary arterial hypertension. Circulation 131: 190-199, 2015.

KOH-TAN HH, MCBRIDE MW, MCCLURE JD, BEATTIE E, YOUNG B, DOMINICZAK AF, GRAHAM D: Interaction between chromosome 2 and 3 regulates pulse pressure in the stroke-prone spontaneously hypertensive rat. Hypertension 62: 33-40, 2013.

KRIZ W: Podocyte is the major culprit accounting for the progression of chronic renal disease. Microsc Res Tech 57: 189-195, 2002.

KRUPKOVA M, LISKA F, SEDOVA L, KRENOVA D, KREN V, SEDA O: Pharmacogenomic analysis of retinoicacid induced dyslipidemia in congenic rat model. Lipids Health Dis 13: 172, 2014.

LANE PH, STEFFES MW, MAUER SM: Estimation of glomerular volume: a comparison of four methods. Kidney Int 41: 1085-1089, 1992.

LANGLEY SR, BOTTOLO L, KUNES J, ZICHA J, ZIDEK V, HUBNER N, COOK SA, PRAVENEC M, AITMAN TJ, PETRETTO E: Systems-level approaches reveal conservation of trans-regulated genes in the rat and genetic determinants of blood pressure in humans. Cardiovasc Res 97: 653-665, 2013.

LAUX-FENTON WT, DONALDSON PJ, KISTLER J, GREEN CR: Connexin expression patterns in the rat cornea: molecular evidence for communication compartments. Cornea 22: 457-464, 2003.

LIAO Y, DAY KH, DAMON DN, DULING BR: Endothelial cell-specific knockout of connexin 43 causes hypotension and bradycardia in mice. Proc Natl Acad Sci U S A 98: 9989-9994, 2001.

LISKA F, CHYLIKOVA B, MARTINEK J, KREN V: Microphthalmia and cataract in rats with a novel point mutation in connexin 50 - L7Q. Mol Vis 14: 823-828, 2008.

LU H, BUCHAN RJ, COOK SA: MicroRNA-223 regulates Glut4 expression and cardiomyocyte glucose metabolism. Cardiovasc Res 86: 410-420, 2010.

MEENS MJ, PFENNIGER A, KWAK BR, DELMAR M: Regulation of cardiovascular connexins by mechanical forces and junctions. Cardiovasc Res 99: 304-314, 2013.

MELOCHE J, LE GUEN M, POTUS F, VINCK J, RANCHOUX B, JOHNSON I, ANTIGNY F, TREMBLAY E, BREUILS-BONNET S, PERROS F, PROVENCHER S, BONNET S: miR-223 reverses experimental pulmonary arterial hypertension. Am J Physiol Cell Physiol 309: C363-C372, 2015.

MORTON SK, CHASTON DJ, HOWITT L, HEISLER J, NICHOLSON BJ, FAIRWEATHER S, BROER S, ASHTON AW, MATTHAEI KI, HILL CE: Loss of functional endothelial connexin40 results in exerciseinduced hypertension in mice. Hypertension 65: 662-669, 2015.

MOZAFFARIAN D, BENJAMIN EJ, GO AS, ARNETT DK, BLAHA MJ, CUSHMAN M, DAS SR, DE FERRANTI S, DESPRES JP, FULLERTON HJ, ET AL.: Executive Summary: Heart Disease and Stroke Statistics-2016 Update: A Report From the American Heart Association. Circulation 133: 447-454, 2016.

O'BRIEN JJ, LI W, PAN F, KEUNG J, O'BRIEN J, MASSEY SC: Coupling between A-type horizontal cells is mediated by connexin 50 gap junctions in the rabbit retina. $J$ Neurosci 26: 11624-11636, 2006.

OKAMOTO K, AOKI K: Development of a strain of spontaneously hypertensive rats. Jpn Circ J 27: 282-293, 1963.

ORLOV SN, DUTIL J, HAMET P, DENG AY: Replacement of (alpha)1-Na-K-ATPase of Dahl rats by Milan rats lowers blood pressure but does not affect its activity. Physiol Genomics 7: 171-177, 2001.

OYAMADA M, OYAMADA Y, TAKAMATSU T: Regulation of connexin expression. Biochim Biophys Acta 1719: 6-23, 2005.

PADMANABHAN S, CAULFIELD M, DOMINICZAK AF: Genetic and molecular aspects of hypertension. Circ Res 116: 937-959, 2015. 
PFAFFL MW: A new mathematical model for relative quantification in real-time RT-PCR. Nucleic Acids Res 29: e45, 2001.

PRAVENEC M, KREN V, LANDA V, MLEJNEK P, MUSILOVA A, SILHAVY J, SIMAKOVA M, ZIDEK V: Recent progress in the genetics of spontaneously hypertensive rats. Physiol Res 63 (Suppl 1): S1-S8, 2014.

REAUME AG, DE SOUSA PA, KULKARNI S, LANGILlE BL, ZHU D, DAVIES TC, JUNEJA SC, KIDDER GM, ROSSANT J: Cardiac malformation in neonatal mice lacking connexin43. Science 267: 1831-1834, 1995.

SAEZ JC, LEYBAERT L: Hunting for connexin hemichannels. FEBS Lett 588: 1205-1211, 2014.

SCHMIDT K, KAISER FJ, ERDMANN J, WIT C: Two polymorphisms in the Cx40 promoter are associated with hypertension and left ventricular hypertrophy preferentially in men. Clin Exp Hypertens 37: 580-586, 2015.

SCHULTE C, MOLZ S, APPELBAUM S, KARAKAS M, OJEDA F, LAU DM, HARTMANN T, LACKNER KJ, WESTERMANN D, SCHNABEL RB, BLANKENBERG S, ZELLER T: miRNA-197 and miRNA-223 predict cardiovascular death in a cohort of patients with symptomatic coronary artery disease. PLoS One 10: e0145930, 2015.

SEDOVA L, LISKA F, KRENOVA D, KAZDOVA L, TREMBLAY J, KRUPKOVA M, CORBEIL G, HAMET P, KREN V, SEDA O: CD36-deficient congenic strains show improved glucose tolerance and distinct shifts in metabolic and transcriptomic profiles. Heredity (Edinb) 109: 63-70, 2012.

SHIELS A, MACKAY D, IONIDES A, BERRY V, MOORE A, BHATTACHARYA S: A missense mutation in the human connexin50 gene (GJA8) underlies autosomal dominant "zonular pulverulent" cataract, on chromosome 1q. Am J Hum Genet 62: 526-532, 1998.

SHIMOYAMA M, DE PONS J, HAYMAN GT, LAULEDERKIND SJ, LIU W, NIGAM R, PETRI V, SMITH JR, TUTAJ M, WANG SJ, WORTHEY E, DWINELL M, JACOB H: The Rat Genome Database 2015: genomic, phenotypic and environmental variations and disease. Nucleic Acids Res 43: D743-D750, 2015.

SILVERSTEIN DM, THORNHILL BA, LEUNG JC, VEHASKARI VM, CRAVER RD, TRACHTMAN HA, CHEVALIER RL: Expression of connexins in the normal and obstructed developing kidney. Pediatr Nephrol 18: 216-224, 2003.

TURNER ST, BAILEY KR, FRIDLEY BL, CHAPMAN AB, SCHWARTZ GL, CHAI HS, SICOTTE H, KOCHER JP, RODIN AS, BOERWINKLE E: Genomic association analysis suggests chromosome 12 locus influencing antihypertensive response to thiazide diuretic. Hypertension 52: 359-365, 2008.

UNOKI H, FURUKAWA K, YONEKURA H, UEDA Y, KATSUDA S, MORI M, NAKAGAWARA K, MABUCHI H, YAMAMOTO H: Up-regulation of cyr61 in vascular smooth muscle cells of spontaneously hypertensive rats. Lab Invest 83: 973-982, 2003.

UNTERGASSER A, CUTCUTACHE I, KORESSAAR T, YE J, FAIRCLOTH BC, REMM M, ROZEN SG: Primer3-new capabilities and interfaces. Nucleic Acids Res 40: e115, 2012.

USUI S, HARA Y, HOSAKI S, OKAZAKI M: A new on-line dual enzymatic method for simultaneous quantification of cholesterol and triglycerides in lipoproteins by HPLC. J Lipid Res 43: 805-814, 2002.

VICKERS KC, LANDSTREET SR, LEVIN MG, SHOUCRI BM, TOTH CL, TAYLOR RC, PALMISANO BT, TABET F, CUI HL, RYE KA, SETHUPATHY P, REMALEY AT: MicroRNA-223 coordinates cholesterol homeostasis. Proc Natl Acad Sci U S A 111: 14518-14523, 2014.

WHITE TW, GOODENOUGH DA, PAUL DL: Targeted ablation of connexin50 in mice results in microphthalmia and zonular pulverulent cataracts. $J$ Cell Biol 143: 815-825, 1998.

WILLENBERG HS, SCHOTT M, SAEGER W, TRIES A, SCHERBAUM WA, BORNSTEIN SR: Expression of connexins in chromaffin cells of normal human adrenals and in benign and malignant pheochromocytomas. Ann N Y Acad Sci 1073: 578-583, 2006.

XIN L, BAI D: Functional roles of the amino terminal domain in determining biophysical properties of Cx50 gap junction channels. Front Physiol 4: 373, 2013.

YOSHIOKA J, CHUTKOW WA, LEE S, KIM JB, YAN J, TIAN R, LINDSEY ML, FEENER EP, SEIDMAN CE, SEIDMAN JG, LEE RT: Deletion of thioredoxin-interacting protein in mice impairs mitochondrial function but protects the myocardium from ischemia-reperfusion injury. J Clin Invest 122: 267-279, 2012. 
YUE X, LIN X, YANG T, YANG X, YI X, JIANG X, LI X, LI T, GUO J, DAI Y, SHI J, WEI L, YOUKER KA, TORRE-AMIONE G, YU Y, ANDRADE KC, CHANG J: Rnd3/RhoE modulates hypoxia-inducible factor 1alpha/vascular endothelial growth factor signaling by stabilizing hypoxia-inducible factor 1alpha and regulates responsive cardiac angiogenesis. Hypertension 67: 597-605, 2016.

ZHAO M, FAJARDO G, URASHIMA T, SPIN JM, POORFARAHANI S, RAJAGOPALAN V, HUYNH D, CONNOLLY A, QUERTERMOUS T, BERNSTEIN D: Cardiac pressure overload hypertrophy is differentially regulated by beta-adrenergic receptor subtypes. Am J Physiol Heart Circ Physiol 301: H1461-H1470, 2011. 